\title{
SEROLOGICAL STUDY ON BRUCELLOSIS IN CATTLE SUFFERING FROM REPRODUCTIVE DISORDERS IN COMPARISON WITH APPARANTLY HEALTH CATTLE IN ASSIUT GOVERNORATE
}

\author{
A.M. KORIEM; S.M. EL BERBAWY and H.A. ABD EL-KADER \\ Animal Health Research Institute - Assiut Provnicial Lab. \\ Email: aymankoriem@yahoo.com
}

\section{ABSTRACT}

Received at: 4/5/2014

A total 1534 blood samples (348 from cattle with history of reproductive disorders include 48 abortion, 56 retained placenta \& 244 repeat breader and 1186 from cattle apparantly health) were collected from different localities in Assiut Governorate, was tested for the detection of antibodies against Brucella spp. The results obtained by Buffer acidified plate antigen test (BAPAT) and Rose bengal test (RBT) as screening tests revealed a positive reactors percentage $4.02 \& 0.51 \%$ respectively. The Brucella positive reactors were subjected to confirmation by Tube agglutination test (TAT) and Rivanol test (Riv.T). The incidence of brucellosis was higher in cattle suffering from reproductive disorders $(3.45 \%)$ in comparasion with apparantly health cattle $(0.51 \%)$. The incidence of brucellosis according to type of reproductive disorders, (abortion, retained placenta \& repeat breader) were $8.33,8.9 \& 1.2 \%$ respectivly, this incidence reflect in addition to brucellosis, some other agents were involved in reproductive disorders.

Key words: Serological Study, Brucellosis, Cattle, Reproductive Disorders.

\section{INTRODUCTION}

Brucellosis is a chronic zoonotic disease caused by Brucella species which are Gram-negative and facultative anaerobic non-motile intracellular bacteria, with Brucella abortus being the principal cause of brucellosis in cattle (Cutler \& Cutler, 2006).

Brucellosis in cattle is usually caused by biovars of Brucella abortus. In some countries, particularly in southern Europe and western Asia, where cattle are kept in close association with sheep or goats, infection can also be caused by B. melitensis (Verger, 1985 \& Jimenez de Bagues et al., 1991). Occasionally, B. suis may cause a chronic infection in the mammary gland of cattle, but it has not been reported to cause abortion or spread to other animals (Ewalt et al., 1997).

Bovine brucellosis is usually caused by Brucella abortus, less frequently by Brucella melitensis and rarely by Brucella suis. It is characterized by abortion, with excretion of the organisms in uterine discharge and milk. Major economic losses result from abortion. Loss of calves, reduced milk yield in females and infertility in males (WHO, 1971).
Bovine brucellosis, caused by Brucella abortus, is a serious zoonotic disease manifested by reproductive disorders such as abortions, infertility, retention of placenta, stillbirth and calf loss in animals, and results in huge economic losses to dairy farmers (Radostits et al., 2000 \& Singh et al., 2002).

Brucellosis is reported as a cause of abortion, retention of placenta, repeat breeding, infertility and prolonged intercalving period due to early embryonic deaths (Roberts, 1999).

Brucellosis is a highly contagious, zoonotic, and economically important bacterial disease of animals worldwide (OIE, 2000). It causes significant economic losses including abortion, loss in milk production, low fertility rates, and cost of replacement of animals (McDermott \& Arimi, 2002).

Brucellosis is a widespread and highly infectious zoonosis disease, with a great economical impact on cattle farming. The infection is caused by Brucella abortus, and it is characterized by abortion, metritis, orchitis and epididymitis. The disease in cattle mainly affects the reproductive organs of infected animals (England et al., 2004). 
Cattle Brucellosis is usually caused by Brucella abortus biovars and occasionally by Brucella melitensis (OIE, 2008). In Egypt, starting from 1998 Brucella melitensis was reported to be the common strain isolated from cattle as reported by Shalaby et al. (2003); Sayour (2004) and Shehata (2004). The disease is mainly characterized by abortion, stillbirths or weak calves and lactating cows may show decrease in milk yield (Matope et al., 2010).

BAPAT and RBPT serological tests revealed the highest rate of sensitivity that guide us to use these tests as screening tests on animals brucellosis. Riv test showing the highest rate of specificity that bearing in mind the BAPAT and RBT positive samples should be confirmed by this test (Montasser et al., 2011).

The prevalence of brucellosis was higher in animals suffering from reproductive troubles $(34.52 \%)$ than among animals apparantly health (6.07\%) (Ammar et al., 2005).

So the objectives of the present investigation was intended to throw light on the incidence of brucellosis in cattle suffering from reproductive disorders in comparison with apparantly health cattle.

\section{MATERIALS and METHODS}

\section{Samples collection :}

A total 1534 blood samples (348 from cattle with history of reproductive disorders include, 48 abortion, 56 retained placenta \& 244 repeat breader, and 1186 from cattle apparantly health) were collected under strict hygienic condition from different localities. Blood samples were sent to the laboratory as soon as possible, were allowed to clot and the sera were obtained by centrifugation and stored at $-20 \mathrm{C}^{\circ}$ until performing serological tests.

\section{Serological Examination:}

All used four antigens were obtained from Veterinary Serum and Vaccine Research Institute Abbasia, Cairo - Egypt.

All sera were screened for antibodies against Brucella by BAPAT as discribed by Angus \& Barton (1984), and RBT as discribed by Alton et al. (1988). All positive serum samples were further retested by TAT and Riv $\mathrm{T}$ as quanitative confirmatory tests described by Alton et al. (1988).

\section{RESULTS}

All data obtained through the investigation were illustrated in Tables 1-3.

Table 1: Incidence of brucellosis in cattle suffering from reproductive disorders in comparison with apparantly healthy cattle.

\begin{tabular}{lccccccccc}
\hline \multirow{2}{*}{$\begin{array}{c}\text { Reproductive status of } \\
\text { examined cattle }\end{array}$} & $\begin{array}{c}\text { Total } \\
\text { number }\end{array}$ & \multicolumn{2}{c}{ RBT } & \multicolumn{2}{c}{ BAPAT } & \multicolumn{2}{c}{ TAT } & & Riv.T \\
\cline { 3 - 10 } & & + ve & $\%$ & + ve & $\%$ & + ve & $\%$ & + ve & $\%$ \\
\hline Cattle apparantly healthy & 1186 & 6 & 0.51 & 6 & 0.51 & 6 & 0.51 & 6 & 0.51 \\
\hline $\begin{array}{c}\text { Cattle with history of } \\
\text { reproductive disorders }\end{array}$ & 348 & 14 & 4.02 & 14 & 4.02 & 12 & 3.45 & 12 & 3.45 \\
\hline
\end{tabular}

Table 2: Incidence of brucellosis in cattle according to type of reproductive disorders.

\begin{tabular}{cccc}
\hline \multirow{2}{*}{$\begin{array}{c}\text { Type of reproductive } \\
\text { disorders }\end{array}$} & No of examined samples & \multicolumn{2}{c}{ Positive seroreactive samples } \\
\cline { 3 - 4 } & & No & $\%$ \\
\hline Abortion & 48 & 4 & 8.33 \\
\hline Retained placenta & 56 & 5 & 1.2 \\
\hline Repeat breader & 244 & 3 & 3.45 \\
\hline Total & 348 & 12 & \\
\hline
\end{tabular}


Table 3: Different serological reactions for seroreactive samples.

\begin{tabular}{|c|c|c|c|c|c|c|c|c|c|c|c|c|c|c|c|c|}
\hline \multirow{3}{*}{$\begin{array}{c}\text { Reproductive } \\
\text { status of } \\
\text { examined cattle }\end{array}$} & \multirow{3}{*}{$\begin{array}{c}\text { Total } \\
\text { Reactors }\end{array}$} & \multicolumn{15}{|c|}{ Serological tests } \\
\hline & & \multirow{2}{*}{\multicolumn{2}{|c|}{ RBPT BAPAT }} & \multicolumn{7}{|c|}{ TAT } & \multicolumn{6}{|c|}{ Rivanol } \\
\hline & & & & $1 / 10$ & $1 / 20$ & $1 / 40$ & $1 / 80$ & $1 / 160$ & $1 / 320$ & Total & $1 / 25$ & $1 / 50$ & $1 / 100$ & $1 / 200$ & $1 / 400$ & Total \\
\hline $\begin{array}{c}\text { Cattle Apparantly } \\
\text { Healthy }\end{array}$ & 6 & 6 & 6 & - & - & - & 2 & 2 & 2 & 6 & 1 & 2 & - & 1 & 2 & 6 \\
\hline $\begin{array}{l}\text { Cattle with history of } \\
\text { reproductive } \\
\text { disorders }\end{array}$ & 14 & 14 & 14 & - & 2 & 2 & 2 & 3 & 5 & 14 & 1 & 3 & 1 & 2 & 5 & 12 \\
\hline
\end{tabular}

\section{DISCUSSION}

Brucellosis is still a major problem in several countries including Egypt. The disease is one of the most serious disease reducing animals productivity and reproductivity and also constitute a public health hazard (Benkirane, 1997).

Surveillance of brucellosis in animals is of great importance and considered the angle stone for better understanding of the disease and improving the control and eradication policy (Fosgate et al., 2003).

In the present study, the obtained results revealed that BAPAT and RBT showed high rate of sensitivity as screening tests where no missed positive cases, these findings agreed with El-Gibaly (1993) and Montasser et al. (2011), while Angus \& Barton (1984) and Gall \& Nielsen (2004) showed that BAPAT was more sensitive and accurate than the other conventional tests for detection of brucella in bovine serum. This was attributed in part to the instability of some of the antigen preparations used in the other tests and also may attributed to the $\mathrm{pH}(4)$ that could overcome the problem of non specific reactions, morever Shalaby et al. (2003) said that BAPAT is a suprior test and can detect low titres missed by TAT. The confirmation with Rivanol test is also rocommended due to its high specificity and reliability in detecting the infected cases without serious number of false positive (Huber \& Nicolleti, 1986).

The number of the positive cases to Rivanol test (Table 3) seemed to be less than that of those on both RBPT, BAPAT and TAT. These results are inagreement with the results reported by Shalaby et al. (2003), it may be due to the precipitating activity of the Rivanol solution on the $\operatorname{IgM}$ as recorded by Pietz and Cowart (1980).

Our findings revealed also that the dilution at which the Rivanol test gave positive results varied from
$1 / 25$ up to $1 / 400$ and this indicates true positive cases because the test determines the agglutinating activity of the IgG after destroying the IgM (Alton et al., 1988). These findings are inagreement with (Shalaby et al., 2003).

The obtained result as shown in Table (1) revealed the prevalence of brucellosis in apparantly health cattle was $(0.51 \%)$. This result agrees with that obtained by Abd El-Hafeez et al. (2001) (0.53\%) and lower than the result recorded by Seddek (1999) $(2.81 \%)$. The variation in the prevaleence of brucellosis may be due to animal population, their susceptibility, vaccination status and the hygienic measures applied.

Correlation between the rate of brucella infecction with the reproductive status of the examined animals as shown in Table (1) revealed that the rate of brucella infection was higher among cattle with a history of reproductive disorders $(3.45 \%)$ than those among cattle apparantly health without history of reproductive disorders $(0.51 \%)$. These finding are inagreement with the results recorded by Hafez (1980); EL-Gamel (2004) and Ammar et al. (2005) who reported that abortion, retained placenta and infertility were the principle guide accompanying infection with brucellosis. On the other hand, animals which were seropositive and had no history of reproductive disorders constitute the major soures of infection and control failure. Similar result was recorded by Njiro et al. (2011) they recorded $3.8 \%$ prevalence of brucellosis in cattle with history of reproductive disorders.

According to the type of reproductive disorders, the obtained results as showed in Table (2) revealed that the incidence of brucellosis relative to abortion was $8.33 \%$. This result agreed with Teferi Degefa et al. (2011) they found that the prevalence of abortion was $8.7 \%$ and Amin et al. (2004) recorded $12 \%$. While lower incidence $3.2 \%$ was reported by Ibrahim (2003). This difference in prevalence rate 
may be due to the variation in cattle husbandry management system.

The gained result Table (2) declared that the incidence of retained placenta was $8.9 \%$.Similar results were also reported by Ahmed et al. (1992) and Amin et al. (2004) they found $7.14 \& 7.41 \%$ respectively. While higher incidence $16.8 \& 18.3 \%$ were recorded by Gebre-Mariam (1996) and Teferi Degefa et al. (2011) respectivly.

The finding of the present study (Table 2) revealed that low incidence of repeat breader $1.2 \%$. Nearly similar finding were noticed by Ahmed et al. (1992) and Amin et al. (2004) they recorded $3.16 \& 1.64 \%$ prevalence of brucellosis respectively.

From these obtained results, we can conclude that Brucella infection still higher among cattle with history of reproductive disorders, which need more efforts and an effective plan for control and eradication of the disease. The high prevalence of abortion and retained placenta together with this low incidence of brucellosis may suggest the presence of other causes of reproductive disease in addition to Brucella.

\section{REFERENCES}

Abdel-Hafeez, M.M.; AbdEl-Kader, H.A.; Ali, M.M.; Bastawrows, A.F. and Seddek, S.R. (2001): Zoonotic importance of brucellosis among farm animals and veterinary field employees at Assiut Governorate. Assiut Vet. Med. J., 44(88): 119-135.

Ahmed, J.U.; Alam, M.G.S.; Rahman, M.M. and Hossain, M. (1992): Seroprevalence of brucellosis in idigenous zebu cattle of Bangladesh. Bangladesh J. Micrbiol., 9: 21-27.

Alton, G.G.; Jones, L.M.; Angus, R.D. and Verger, J.M. (1988): Techniques for the brucellosis laboratory. Institut National de la Recherche Agronomique, Paris, 190 pp.

Amin, K.M.R.; Rahman, M.B.; Kabir, S.M.L.; Sarkar, S.K. and Akand, M.S.I. (2004): Serological Epidemiology of Brucellosis in Cattle of Mymensingh Districts of Bangladesh. J. Anim. Vet. Adv.,3(11): 773-775.

Ammar, K.M.; AL-Gaabary, M.H.; Osman, S.A. and Hegazy, Y.M.A. (2005): Some studies on brucellosis among ruminants in Gharbia Governorate. $8^{\text {th }}$ Sci. Cong., Egyptian Society For Cattle Diseases, 11-13 Dec., Assiut, Egypt.

Angus, R.D. and Barton, C.E. (1984): The production and evaluation of a buffered plate antigen for use in a presumptive test for brucellosis. In Proc. 3rd International
Symposium on brucellosis, Algiers, Algeria. Dev. biol. Standard., 56, 349-356.

Benkirane, A. (1997): Analysis of the intrenational animals health code for brucellosis (with special focusin north africa and the middle east). J. Egypt Vet. Med. Ass., 75 (1): 5-6.

Cutler, S.J. and Cutler, R.R. (2006): Brucellosis, the most common bacterial zoonosis. The Biomedical Scientist, 50 (4): 336-341.

EL-Gamel, A.M. (2004): Control trials of some occupational zoonotic diseases of Egyptian farmer. M.V.Sc. Thesis (Zoon), Fac. Vet. Med., Tanta University, Kafr El-Sheikh Branch.

El-Gibaly, S.M. (1993): Correlation between serotests and isolation of Brucella melitensis in an infected sheep farm. Proc. 2 Sci. Cong. Socity for cattle Disease, Assiut, 194-203.

England, T.; Kelly, L.; Jones, R.D.; MacMillan, A. and Wooldridge, M. (2004): A simulation model of brucellosis spread in British cattle under several testing regimes. Prev. Vet. Med., 63: 63-73.

Ewalt, D.R.; Payeur, J.B.; Rhyan, J.C. and Geer, P.L. (1997): Brucella suis biovar 1 in naturally infected cattle: a bacteriological, serological, and histological study. J. Vet. Diagn. Invest., 10: 417-420.

Fosgate, G.T.; Adesiyun, A.A.; Hird, D.W.; Johnson, W.O.; Hietala, S.K.; Schurig, G.G. and Diptee, M.D. (2003): Evaluation of brucellosis RB51 vaccine for domestic water buffalo in Ttrinidad. Prev. Vet. Med., 58: 211-225.

Gall, D. and Nielsen, K. (2004): Serological diagnosis of bovine brucellosis: a review of test performance and cost comparison. Rev. Sci. Tech. Off. Int. Epiz., 23 (3): 989-1002.

Gebre-Mariam, T. (1996): Survey on prepartum and pospartum reproductive problems of dairy cattle in Mekele and its environments. DVM Thesis, FVM, AAU Debre Zeit, Ethiopia.

Hafez, E.S.E. (1980): Reproduction in Farm Animals $3^{\text {rd }}$ ed. Lea and Febger, Philadelphia, chapter IV: Reproductive failure, pp. 449-503.

Huber, J.D. and Nicolleti, P. (1986): Comparsion of the results of card, rivanol, complement fixation and milk ring test with the isolation rate of Br.abortus from cattle. Am. J. Vet. Res., 47:1529-1531.

Ibrahim, O. (2003): Study in major reproductive health problems of smallholder dairy farms in and around Kombolcha. DVM Thesis, FVM, AAU Debre Zeit, Ethiopia.

Jimenez de Bagues, M.P.; Marin, C. and Blasco, J.M. (1991): Effect of antibiotic therapy and strain 19 vaccination on the spread of Brucella melitensis within an infected dairy herd. Prev. Vet. Med., 11: 17-24. 
Matope, G.; Behabhe, E.; Muma, J.B.; Lund, A. and Skjerve, E. (2010): Risk factors for Brucella species infection in small holder household herds. Epidemiology and Infection, 139: 157164.

McDermott, J.J. and Arimi, S.M. (2002): Brucellosis in sub-Saharan Africa: Epidemiology, Control and Impact. Veterinary Microbiology, 90(14): 111-134.

Montasser, A.M.; Affi, M.M.; EL-Bayoumy, E.M.; Abdul-Raouf, U.M. and Mohamad, H.A. (2011): Efficiency of serological tests for detection of brucellosis in ruminant at south provinces of Egypt. Global Veterinaria 6(2): 156-161.

Njiro, S.M.; Kidanemariam, A.G.; Tsotesti, A.M.; Katsande, T.C.; Mnisi, M.; Lubisi, B.A.; Potts, A.D.; Baloyi, F.; Moyo, G.; Mpofu, J.; Kalake, A. and Williams, R. (2011): Astudy of some infectious causesof reproductive disorders in cattle owned by resource-poor farmers in Gauteng Province, South Africa. J.S. Afr. Vet. Ass.,82(4): 213-218.

OIE (2000): "Bovine brucellosis," in Manual of Standards for DiagnosticTests and Vaccines, pp. 328-345, OIE, Paris, France, $4^{\text {th }}$ edition.

OIE (2008): Mannual of the diagnostic tests and vaccines for terrestrial animals, Vol.1, 5th Edition (Office International Des Epizooties, Paris, France).

Pietz, D.E. and Cowart, W.O. (1980): Use of Epidemiological data and serological tests in bovine brucellosis. J. Am. Vet. Med. Ass., 177:1221-1226.

Radostits, O.M.; Gay, C.C.; Blood, D.C. and Hinchcliff, K.W. (2000): Veterinary Medicine: a textbook of the diseases of cattle, sheep, pigs, goats and horses. $9^{\text {th }}$ ed. W. B. Saunders, London, pp. 1877.

Roberts, S.J. (1999): Veterinary Obstetrics and Genital Diseases (Theriogenology). 2nd ed. CBS publishers and distributors, New Delphi,
India, chapter XIII: Infertility in the cow, pp. 499.

Sayour, A.E. (2004): The use of recent bacteriological techniques in the differentiation of Brucella group of microorganisms. Ph.D. Thesis, Microbiology, Fac. Vet. Med., Cairo University.

Seddek, S.R. (1999): Serological studies on Brucella infection in cattle, sheep and goat. Assiut Vet. Med. J., 42 (83): 216-227.

Shalaby, M.N.; Ghobashy, H.M.; El-Bayomy, E.M. and Saleh, W.M. (2003): Prevalence of brucellosis among farm animal species in some governorates in Egypt. Proceedings of the Seventh Scientific Congress, Egyptian Society for Cattle Diseases, Assiut, Egypt, pp. 271-282.

Shehata, A.E. (2004): Immunological studies on Brucella microorganisms in farm animals in Bani Suef governorate. M.V.Sc. Thesis (Microbiology), Fac. Vet. Med., Cairo University, Bani Suef Branch.

Singh, G.; Sharma, D.R.; Sandhu, K.S. and Dhand, N.K. (2002): Economic losses occurring due to bovine abortions in Punjab. In: 10th International Congress of Asian-Australasian Association of Animal Production Societies, 23-27 September. Ashoka Hotel, New Delhi, India.

Teferi Degefa; Asmamaw Duressa and Reta Duguma (2011): Brucellosis and Some Reproductive problems of Indigenous Arsi Cattle in Selected Arsi zone's of Oromia Regional State, Ethiopia. Global Veterinaria, 7(1): 45-53.

Verger, J.M. (1985): B. melitensis infection in cattle. In: Brucella melitensis, Plommet \& Verger, eds. Martinus Nijhoff Publ., DordrechtBoston-Lancaster. 197-203.

WHO (1971): Technical Report Series, Joint FAO/WHO Expert Committee in Brucellosis, $5^{\text {th }}$ Report: No. 464.
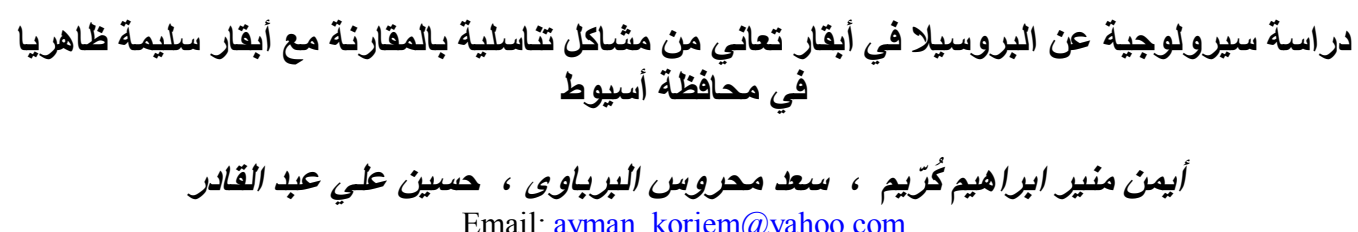

Email: ayman_koriem@yahoo.com

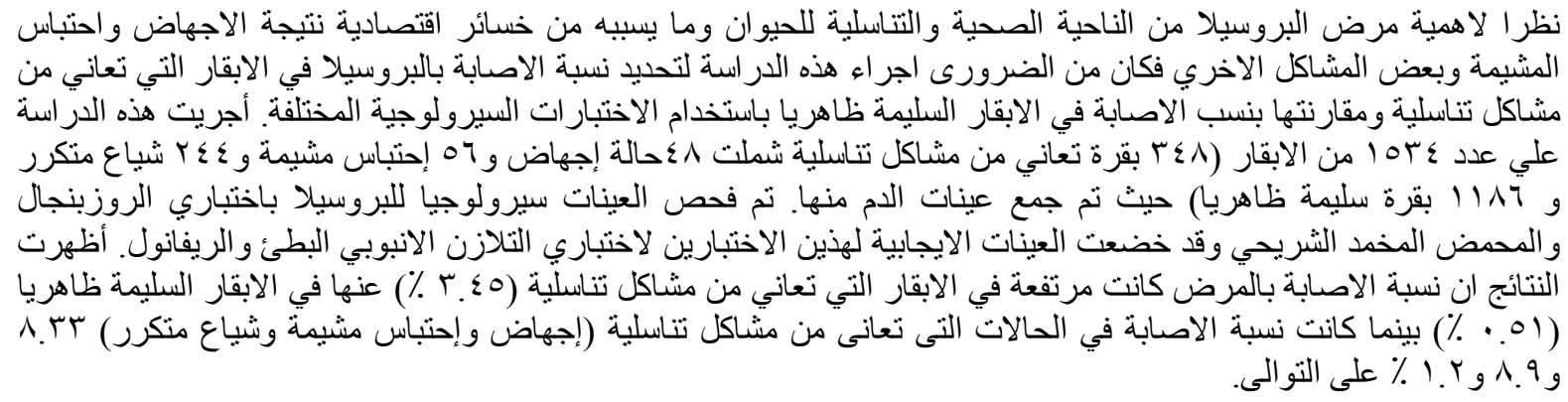

